\title{
Risk Based Decision Support for Final Closing Section of a Sea Dike
}

\author{
Sung Hyun Jee ${ }^{1}$, Seong Hae $\mathrm{Kang}^{2}$, Jeong Hwan $\mathrm{Kim}^{3}$, and Jong Won Seo ${ }^{4}$
}

\begin{abstract}
A sea dike construction has been increased in Korea because of the actively deployed reclamation project in basis of efficient application in land. The degree of completion in sea dike construction is affected by final closing construction, which has a lot of uncertainty that often results in higher accidents rate. Therefore, this research identified risk factors of final closing construction and classified them. This research examines the likelihood and its impact for each risk factor and calculates the risk degree as to the risk matrix. Based on this, the impact and the environmental conditions that affect to risk factors are investigated and further responsive methods are established for each risk factor. Ultimately, this research attempts to provide the risk retrenchment method for inspectors by proposing risk estimation model, responsive action list, and risk management process.
\end{abstract}

\section{Keywords: Final Closing Section, Sea Dike, Risk analysis, Decision Support}

\section{INTRODUCTION}

\section{A. Problem Statement}

With the economy development plan in 1960s, a sea dike construction has been increased because of the actively deployed reclamation project in basis of efficient application in land. And reclamation project such as Suk Moon, Sap Kyoo Chun, Sihwa, Sae Man Keum project is being carried out forward. The amount of sea dike construction has gradually increased since 2006.

By the way, sea dike has considerable casualties comparing with other construction. The high proportion of sea dike construction always occupy in the cause of injuries or deaths of civil engineering

The degree of completion in sea dike construction is affected by final closing construction, which has great influence on the project because of its environmental sensitivity. And the construction of final closing section has many uncertainty and instability, so it significantly influences on construction cost and duration on project. Despite of these uncertainties, most of project was performed by subjective decision of supervisor. Also, this study found a lack of understanding for risk management of final closing section construction and that information system is incomplete. And information of final closing section is mostly stability for dam body and there is no example about guideline of risk model which effectively performs response for each risk.

\section{B. Objective and Significant}

Previously attempted studies on final closing construction have focused on engineering approach on system stability, or velocity and weight in construction, differences of the tidal range considered stability. Relatively few studies have been devoted to risk management of final closing construction, which results in lack of basic data upon the possible risk factor or status in construction progress. Also, the result of interview and survey shows that there have been numerous impediments in practical project due to the lack of established systematic reference on risk management of final closing construction.

This work aims to develop risk model and analyze the importance of risk based on this model in final closing construction. And it builds optimized response method on the identified risk factor, thereby; provide the alternative management method to reduce risk in practical project. In addition, it establishes guideline model to provide reference data in practice. This guideline will be set up through surveys on experienced workers in final closing based on risk model.

By proceeding research on alternative risk management that has not previously attempted, this work will be ultimately beneficial of risk retrenchment effect in final closing construction as it provides identification of unestablished risk factor, development of risk estimation model, calculation of risk evaluation values on each factors, and counterplan-building to the factors

\section{Hypothesis}

This work assumed three hypotheses in order to prove this research's availability. The hypothesis is related to risk management for final closing section and usefulness of established risk assessment model.

First, final closing section experts who are construction manager and labor will have awareness of risk for sea dike. This hypothesis is that construction worker will use risk assessment model at planning decision making for final closing section.

Second, it can establish risk assessment model which reflects decision process of manager. This hypothesis is

${ }^{1}$ Researcher, Kunwon Engineering Co., LTD., Research \& Development Center, limpbb@naver.com

2 General manager, SK E\&C Co., LTD., shgang@sk.com

${ }^{3}$ Researcher, Hanyang University, Dept. of Civil and Environmental Engineering, kimjh0418@gmail.com

${ }^{4}$ Associate Professor, Corresponding Author, Hanyang University, Dept. of Civil and Environmental Engineering, jseo@hanyang.ac.kr 
that established risk assessment model is made by final closing section expert's opinion and their experience.

Third, established risk model will match historical data. This hypothesis is that established model will have usefulness in actual construction. In other words, risk assessment model can be applicable to real construction site.

So, hypothesis is shown the follow in brief.

1. Construction manager will plan decision making by using risk model

2. Decision process of manager can be captured into a risk model

3. Established risk model will match historical accident data

\section{Research Procedure}

In briefly, the research procedure is shown in Figure 1. The purpose of this research is that establish risk assessment model and appropriate risk response, finally suggest risk guideline model and process.

So, it performed literature review about risk management for final closing section and general civil engineering construction. It focuses that how much perform risk management for final closing section. And it found that what kind of risk management process or assessment model is used in general civil engineering construction.

Second, it collected data for establishing risk model. The data included risk awareness of final closing expert and risk factors, environment factors which influence on building final closing section.

And then, it established risk assessment model with collected data. The risk model could check a likelihood and impact of risk and analysis risk assessment.

And then, it performed risk analysis and survey response. Likelihood and impact of risk factor for risk analysis and response list is gotten from interviewing with final closing expert and survey.

Lastly, it tested an established model with historical accident data. It found information about accident data of final closing section. In historical accident data, it got accident cause and imperfection. And then, it matched cause and imperfection with identified risk factor.

\begin{tabular}{|c|c|}
\hline $\begin{array}{l}\text { Literature } \\
\text { Review }\end{array}$ & - Final Closing section of sea dike \\
\hline $\begin{array}{c}\text { Data } \\
\text { Collection }\end{array}$ & $\begin{array}{l}\text { - Risk recognition of manager } \\
\text { - Risk and environment factor }\end{array}$ \\
\hline Modeling & - Establish risk model based on collected data \\
\hline $\begin{array}{l}\text { Analysis \& } \\
\text { Response }\end{array}$ & $\begin{array}{l}\text { - Survey likelihood, impact and then analyze } \\
\text { - Respond to each risk factor }\end{array}$ \\
\hline $\begin{array}{c}\text { Model } \\
\text { Validation }\end{array}$ & - Match risk model with historical accident data \\
\hline
\end{tabular}

\section{RESEARCH BACKGROUND}

\section{A. Final Closing Section}

A sea dike construction is center for land reclamation, and final closing has primary importance in a sea dike construction. This construction can be divided into general phase which consists of initial and middle stage, and final phase. In general phase, it is fairly simple to formulate embankment materials or methods because tidal velocity and current speed difference are comparably small. However, final phase requires special materials and methods which is different from general phase because inner and outer water height differences and tidal velocity are immensely increased. This phase should be finished within a short period of time with full efforts in order to minimize hazardous terms. It is final closing construction that demands particular materials and methods with optimized competence for construction (Rural Development Corporation, 1995).

In a reclamation project, sea dike construction is very important process. And in a sea dike construction, final closing section construction is significant process. Final closing section is finish process of sea dike construction, in other words, final closing section finally connects body of sea dike.

The plan for final closing construction is determined by the environmental condition, stability, execution, economic feasibility. Typical inquiries are shown in Table 1 (Rural Development Corporation, 1995).

TABLE I

TYPICAL INQUIRIES FOR FINAL CLOSING CONSTRUCTION PLAN

\begin{tabular}{c|l}
\multicolumn{2}{c}{ TYPICAL INQUIRIES FOR FINAL CLOSING CONSTRUCTION PLAN } \\
\hline Typical inquiries for final closing construction plan \\
\hline $\begin{array}{c}\text { Location } \\
\begin{array}{c}\text { Section } \\
\text { congation } \\
\text { of the ground }\end{array}\end{array}$ & $\begin{array}{l}\text { Elongation in final closing section is determined by } \\
\text { examining water condition, the amount of } \\
\text { construction, duration }\end{array}$ \\
\hline $\begin{array}{c}\text { Final closing } \\
\text { time }\end{array}$ & $\begin{array}{l}\text { Time is determined by examining meteorology and } \\
\text { maritime condition, and relevance with other } \\
\text { process }\end{array}$ \\
\hline $\begin{array}{c}\text { Establish plan } \\
\text { Establish execution plan based on maritime and } \\
\text { current speed. }\end{array}$ \\
\hline $\begin{array}{c}\text { Calculate the } \\
\text { movement of } \\
\text { the sea }\end{array}$ & $\begin{array}{l}\text { Calculate tide, current speed, inner and outer water } \\
\text { height differences during before and middle in final } \\
\text { closing. }\end{array}$ \\
\hline
\end{tabular}

The Figure 2 presents design process of final closing section. In the design process, this work found factor which influence on risk in order to establish risk assessment model. 


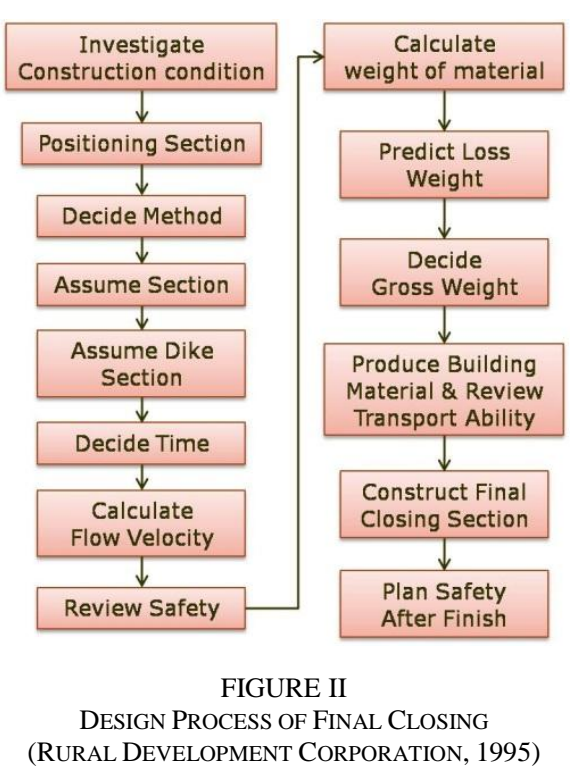

\section{B. Risk Management}

Risk is considered as 'a possibility not to obtain expected result, a gap between expectation and reality, uncertainty or the result of it.' (Rothkopf, 1975)

Risk in construction industry has an inclusive character, which includes not only lost and damage but also obtainment and opportunity. This sort of risk, which is contrary to insurance risk with passive perspective, is described as speculative risk, dynamic risk, market risk, or systematic risk.

Also, risk in construction industry is classified as physical risk, environmental risk, acts of god, political and legal risk, or financial and legal risk by its features. Besides, it is possible to approach and classify the risks in terms of time dimension: validation analysis phase, planning-design phase, contract-operation phase, appropriation-usage and maintenance phase. Finally, in terms of spatial dimension in risk occurrence, it can be divided into business unit risk, construction company level risk, construction industry level risk, and national economic level risk (Kim, 2004).

Based on above concepts of risk, risk management proceeds as follow.

Risk management includes the process of carrying out risk planning, identification, analysis, response planning, monitoring and control on a project. Project risk is always in the future. Risk is an uncertain event or condition that, if it occurs, has an effect on at least one project objective.

Identify risk is the process of determining which risk may influence the project and documenting their characteristics. This process is an iterative process because new risk may evolve or become known as the project progresses through its life cycle.

Perform qualitative risk analysis is the process of prioritizing risk for further analysis or action by assessing and combining their probability of occurrence and impact. Organizations can improve the project's performance by focusing on high-priority risk. Perform this analysis assesses the priority of identified risk using their relative likelihood of occurrence, the corresponding impact on project objectives.

Risk response is the process of developing options and actions to enhance opportunities and to reduce threats to project objectives. It follows risk analysis. Planned risk responses must be appropriate to the significance of the risk. Selecting the best risk response from several option is often required (Project Management Institute, 2008).

\section{Literature Review}

This research searched about final closing section and risk management in general construction. This work focused on risk assessment model for final closing section.

KRCC (Korea Rural Community Corporation, 2006) established safety management system that decide forecast of decrepit progress of tidal gate bridge in Sae Man Keum and appropriate repair time and KDF (Korea Development of Farmland Laboratory, 1995) researched construction plan which considers workability and damage control that considers unexpected damage during constructing sea dike.

In the final closing construction, this work found a lack of information system or example for risk estimation model and risk management process. And research of final closing is mostly about safety management or they didn't suggest concrete concept of risk.

And risk management in general construction only researched risk checklist or analysis risk degree.

Kim et al. (2008) provided risk management in the demolition site. This study identifies risk factors in demolition for site managers to provide a basis of more systematic approach to effectively control the site. Choi et al. (2005) suggested safety impact assessment on construction project. The suggested model included information survey and scenarios, classification of safety impact factors occurred by design and construction, and quantitative estimation of magnitude and frequency. Park et al. (2009) suggested the checklist that includes reducing both time, and the money, improving quality, safety procedures and everything as explain above based on the experience and knowledge in Construction Phase. Shin and Cha (2008) suggested that by quantifying each risk factor from an extensive industry survey, the proposed tool can enhance the reliability of each factor weight and also the weights are categorized from a various perspectives.

\section{RESEARCH METHOD}

\section{A. Data Collection}

\section{1) Survey Risk Awareness}

To figure out risk awareness of experts for final closing section, this study conducted a survey of experts in design and construction division. In a total, 15 people answered the questions, and each of them has more than 5 years' experience.

To the first question, except 3 of them, all people answered that risk management is needed for final closing 
section. This research found that although expert think a necessity of risk assessment model and risk management process, they didn't actually perform risk management as about $50 \%$ to $80 \%$. Besides, they didn't have risk management expert or information system such as risk assessment model, risk response list, risk management flow chart for final closing section.

Thus, it proves hypothesis one, which is Construction manager will plan decision making by using risk model. They have been already aware of the needs of risk management in sea dike construction. Only because of the absent of risk model to use, they couldn't fulfill the risk management.

\section{2) Identify Risk Factor}

This work identified risk factors and environmental conditions in order to build a risk assessment model. All risk factor is possible events during constructing a final closing section. There are so many kinds of risk, but this research focused on construction engineering risk. The engineering risk is related to accident or collapse which can be generated under construction. And environment factor is impact condition which influences on building a final closing section.

Risk factor is identified by survey, literature review, and interview with experts. Rural Development Corporation (1995) and Kang (2010) established risk factor and accident cause and imperfection. It got risk from the book and paper and then it again identified risk through interviewing with expert according to environment impact factor. And it divided risk as two categories; engineering and general. Risk is also divided into project phase such as planning, preparation, operating, managing. Planning phase is that decides design condition and draw up a floor plan for a final closing. Preparation phase is that arranges material and equipment, worker before building a final closing. Operating phase is that actually build a final closing. Finally, managing phase is that monitor or control a final closing section and clean up the construction site.

First, engineering risk factors are influenced by environmental conditions. Environmental conditions are related to considering condition at design construction and building a final closing section. And there are three project phases; planning, preparation, operating. Managing phase is not related to environment factor because the final closing construction finished at the managing phase. Table 2 shows engineering risk factors. There is the most risk factor in the operating phase because engineering risk is mostly related to construction operation.

TABLE II

ENGINEERING RISK FACTORS

\begin{tabular}{c|l}
\hline Project Phase & \multicolumn{1}{|c}{ Risk Factor } \\
\hline \multirow{3}{*}{ Planning } & Plan Ignores Weather Forecast \\
\cline { 2 - 2 } & Mis-calculated of Water Pressure \\
\cline { 2 - 2 } & Inadequate Preparation for Existing Water Condition \\
\hline Preparation & Fault of Putting Optimal Equipment \\
\hline
\end{tabular}

\begin{tabular}{l|l}
\hline \multirow{4}{*}{ Operating } & Fault of Putting Essential Personnel \\
\cline { 2 - 2 } & Fault of Managing Quantity of Soil heap \\
\cline { 2 - 2 } & Fault of Managing Quantity of Rock heap \\
\hline & Work Delay due to Bad Weather \\
\cline { 2 - 2 } & Material Lost due to Wave \\
\cline { 2 - 2 } & Fault of Building Filter Mat \\
\cline { 2 - 2 } & $\begin{array}{l}\text { Time Management } \\
\text { (No Concern of Work Delay for each Operation) }\end{array}$ \\
\cline { 2 - 2 } & Fault of Managing Build Time for each Size \\
\hline
\end{tabular}

And general risk is not related to environment factor. It is just possible risk during performing construction. And there are four project phases; planning, preparation, operating, managing. Table 3 shows general risk factors. There is the most risk factor in the planning phase.

TABLE III

GENERAL RISK FACTORS

\begin{tabular}{|c|c|}
\hline & FACTOF \\
\hline Project Phase & Risk Factor \\
\hline \multirow{9}{*}{ Planning } & Planning Error of Final Closing Section \\
\hline & No Consideration for Ground Condition \\
\hline & $\begin{array}{l}\text { Fault of Expectation Putting Quantity } \\
\text { (No Consideration Settlement during Construction) }\end{array}$ \\
\hline & $\begin{array}{l}\text { Fault of Management of Selecting Optimal } \\
\text { Construction Method }\end{array}$ \\
\hline & Fault of Treating Additional Personnel Expenses \\
\hline & Fault of Treating Additional Equipment Expenses \\
\hline & Plan of Securing Source of Supply \\
\hline & Fault of Taking Measure to Civil Complaint \\
\hline & Fault of Evacuation Plan for Ship in Work site \\
\hline \multirow{5}{*}{ Preparation } & Fault of Managing Pre-Scenario \\
\hline & Unconfirm Equipment's Road \\
\hline & $\begin{array}{l}\text { Fault of Preparing Measurement about Construction } \\
\text { Section }\end{array}$ \\
\hline & Delay of Material Preparation \\
\hline & Fault of Preparation at Nightwork (Generator) \\
\hline \multirow{6}{*}{ Operating } & Fault of Control of Putting Material Time \\
\hline & Fault of Management of Putting Equipment \\
\hline & Fault of Equipment for Building Sheet \\
\hline & Fault of Injection Management for each Size \\
\hline & Fault of Control Management of Subcontractor \\
\hline & Fault of Control Management of Construction Manager \\
\hline \multirow{7}{*}{ Managing } & Fault of Treating Waste \\
\hline & Fault of Managing Design Change \\
\hline & Fault of Finishing Additional Work Schedule \\
\hline & Fault of Finishing Additional Material Schedule \\
\hline & $\begin{array}{l}\text { No Consideration for Minimum Surface Construction } \\
\text { for Stability }\end{array}$ \\
\hline & $\begin{array}{l}\text { No Consideration for Reinforcement Method at Defect } \\
\text { Occurrence }\end{array}$ \\
\hline & $\begin{array}{l}\text { No Consideration for Obtaining Material at Defect } \\
\text { Occurrence }\end{array}$ \\
\hline
\end{tabular}

\section{3) Important Environmental Conditions}

This work derived the environmental conditions which influence on final closing construction. As a result, six environmental conditions are drawn through analysis of design phase in final closing and precedent case study, 
and interview with professionals. It includes tide, lockage, the velocity of a moving fluid, precipitation, wind velocity, and temperature.

To confine the range of above environmental conditions, this study selected Gun San region. First reason is that Sae Man Keum Project, the largest scale construction, has been done in this area with equivalent scale of sea-dike construction. Second, since the tidal difference in west coast is comparably massive than other region, it would be advantageous to apply other region with least range error. The lockage means an absolute value of tidal difference. Water fluidity is built by accordance with condition of final closing construction design in Tideland Reclamation in Korea published from Korea Rural Development Corporation. Temperature refers to general condition in Korea. Data on tidal difference refers to Korea Hydrographic Oceanographic Administration, and temperature, velocity, and precipitation refers to meteorology annals in 2006.

First, this work refers to tide and ebb data at one hour from Korea Hydrographic Oceanographic Administration (KHOA). Including the maximum daily value and the minimum daily value of tide and ebb on March in 2006, six hourly tide and ebb data are referred.

Second, it got weather information in 2006 from Korea Meteorological Administration. And this work abstracted necessary data from weather information such as average value. The data is temperature, rainfall, and wind, and data value is average on month.

Lastly, flow velocity is gotten from Rural Development Corporation (1995). Table 4 shows standard of environmental conditions.

TABLE IV

STANDARD OF ENVIRONMENTAL CONDITIONS

\begin{tabular}{|c|c|c|c|}
\hline \multicolumn{4}{|c|}{ Standards of Environmental Conditions } \\
\hline \multirow{3}{*}{ Tide (m) } & $-2 \sim 2$ & \multirow{4}{*}{$\begin{array}{l}\text { Rainfall } \\
(\mathrm{mm})\end{array}$} & $0 \sim 10$ \\
\hline & $2 \sim 6$ & & $10 \sim 20$ \\
\hline & $6 \sim 9$ & & $20 \sim 30$ \\
\hline \multirow{3}{*}{$\begin{array}{l}\text { Difference of } \\
\text { Water Surface } \\
\text { Elevation }(\mathrm{m})\end{array}$} & $0 \sim 4$ & & $30 \sim 40$ \\
\hline & $4 \sim 8$ & \multirow{4}{*}{$\begin{array}{l}\text { Wind } \\
(\mathrm{m} / \mathrm{sec})\end{array}$} & Weak Wind $(0 \sim 2.5)$ \\
\hline & $8 \sim 10$ & & Medium Wind $(2.5 \sim 5)$ \\
\hline \multirow{6}{*}{$\begin{array}{l}\text { Flow Velocity } \\
\quad(\mathrm{m} / \mathrm{sec})\end{array}$} & $0 \sim 2$ & & Strong Wind $(5$ 7.5) \\
\hline & $2 \sim 4$ & & $\begin{array}{l}\text { Very Strong Wind } \\
(7.5 \sim 10)\end{array}$ \\
\hline & $4 \sim 6$ & \multirow{4}{*}{$\begin{array}{c}\text { Temperature } \\
\left({ }^{\circ} \mathrm{C}\right)\end{array}$} & \\
\hline & \multirow{3}{*}{$6 \sim 8$} & & $0 \sim 10$ \\
\hline & & & $10 \sim 20$ \\
\hline & & & $20 \sim 30$ \\
\hline
\end{tabular}

\section{B. Build a Model}

This work has established risk estimation model to analyze risk factors. It is formulated each by engineering risk factor and general risk factor.

Engineering risk estimation model consists of engineering risk factor and environmental conditions, while general risk model only consists of general risk factor. Each model provides confirmation check of likelihood of risk factors and its further impact.

Engineering risk estimation model also provides confirmation check of probability and its influence to each environmental condition. General risk estimation model is comprised of check the likelihood and its impact of risk factor in each project phase. The likelihood will analyze probability of risk factor in qualitative terms. The impact degree refers the levels of further consequences upon the construction when having incidence. Next chapter will cover the further research on occurrence probability and impact degree.

Each risk estimation model is built through Excel 2007. If likelihood and impact degree is put into the sheet, risk degree is automatically calculated. Workers can easily determine risk judgment based on the above degree.

In addition, each risk estimation model is formulated by project phases. Project phases are divided into planning phase, preparation phase, operating phase, and managing phase. The reason of division by project phases is to facilitate risk factor check in each phase when workers are in practical project or construction.

Engineering risk estimation model refers a model, which can obtain risk degree by checking likelihood and its impact of risk factor under certain environmental conditions. For instance, if the risk likelihood and impact degree to Faults of Management Plan at Bad Weather are checked in $0-2 \mathrm{~m} / \mathrm{sec}$ of fluid velocity, risk degree is automatically calculated on Excel sheet. Then, inspectors or workers can get risk degree on environmental condition. Consequently, engineering risk estimation model provides a guideline for proper reaction in project by giving and analyzing estimated risk degree for each environmental condition.

\section{Risk Analysis}

This work takes qualitative method in analyzing risk degree. The qualitative method determines likelihood and impact degree of identified risk factors by ranks by professionals or hazardous evaluation group. This method is exploited when there is insufficient data which renders not to quantify identified risk factor or non-repetitive form of risk factor. In the qualitative analysis phase, risk factors are ranked by potential hazardous which affects to the industrial objective. It determines the impacts and occurrence probability of discerned factors. The analysis on the risk factor likelihood and impacts should follow previously defined analysis method and tools in this phase (Kim, 2010).

The results of this chapter is indebted not to the case study for certain construction but to the interview and survey for experienced professionals. It is to provide general or universal risk estimation guideline model. For example, it is a result of qualitative analysis upon the likelihood of certain risk factors under the certain environment and further consequences degree. The final objective of the analysis lies in providing general reference for workers under final closing construction through risk estimation model. 
In order to establish a risk estimation model, it is necessary to assess the risk degree with an appropriate risk value. Table 5 shows standard of likelihood and impact. This standard was proposed by Edwards (1995). Level ' $A$ ' to ' $E$ ', degree of likelihood and impact is more and more strong. Based on this standard, risk degree is calculated. Moreover, temporary points are assigned for easy calculation. For example, by using risk degree equation, likelihood is 0.3 and impact is 0.3 , finally risk degree is 0.09 .

TABLE V

STANDARD OF LIKELIHOOD AND IMPACT (LESLIE EDWARDS, 1995)

\begin{tabular}{c|c|c|c|c|c}
\hline \multicolumn{3}{|c|}{ Likelihood } & \multicolumn{3}{c}{ Impact } \\
\hline Level & Decision & Point & Level & Impact & Point \\
\hline a & Unlikely as not & 0.1 & $\mathrm{a}$ & Nuisance Impact & 0.1 \\
\hline $\mathrm{b}$ & As Likely as not & 0.3 & $\mathrm{~b}$ & Least Loses of Range & 0.3 \\
$\mathrm{c}$ & Likely & 0.5 & $\mathrm{c}$ & Manageable Loses & 0.5 \\
$\mathrm{~d}$ & Almost Certain & 0.7 & $\mathrm{~d}$ & Largest Loses of Range & 0.7 \\
\hline $\mathrm{e}$ & Certain & 0.9 & $\mathrm{e}$ & Most Serious & 0.9 \\
\hline
\end{tabular}

Risk degree is calculated by following equation.

Risk Degree $=$ Likelihood $(\mathrm{L})$ X Impact $(\mathrm{I})$

Figure 3 shows that left matrix is general risk matrix and right matrix shows that is given temporary point for each level by this work. And Table 6 presents standard of risk degree based on risk analysis matrix.
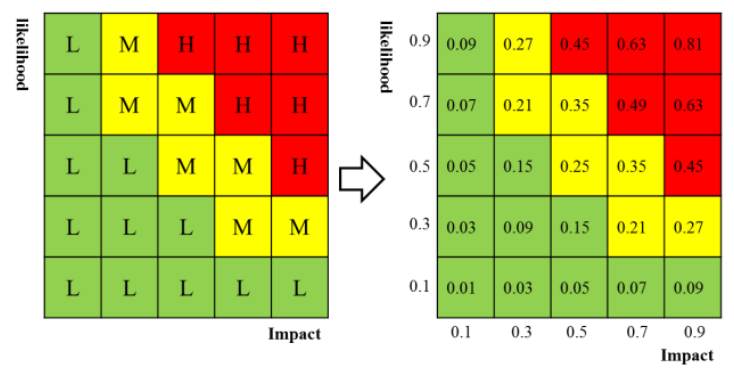

FIGURE III

RISK ANALYSIS MATRIX

TABLE VI

STANDARD OF RISK DEGREE

\begin{tabular}{c|c}
\hline Risk Degree $(\mathrm{L} \times \mathrm{I})$ & Level \\
\hline $0.01 \sim 0.15$ & Low $(\mathrm{L})$ \\
\hline $0.21 \sim 0.35$ & Moderate $(\mathrm{M})$ \\
\hline $0.45 \sim 0.81$ & $\operatorname{High}(\mathrm{H})$ \\
\hline
\end{tabular}

And in the many results of survey, risk degree is decided by a part of high frequency. If number of yellow part is 5 , green is 3 , red is 2 , finally risk degree is yellow part. And this work assumed one thing that risk assessment is equal in the same part. For example, 0.09 and 0.15 is equal part that is green. And Table 7 presents example of risk degree's level.
TABLE VII

EXAMPLE OF RISK LEVEL

\begin{tabular}{c|l}
\hline Risk Level & \multicolumn{1}{c}{ Explanation } \\
\hline High & $\begin{array}{l}\text { Unacceptable. Major disruption likely different approach } \\
\text { required. Priority management attention required }\end{array}$ \\
\hline Moderate & $\begin{array}{l}\text { Some disruption different approach may be required } \\
\text { additional management attention may be needed }\end{array}$ \\
\hline Low & $\begin{array}{l}\text { Minimum impact } \\
\text { Minimum oversight needed to ensure risk remains low }\end{array}$ \\
\hline
\end{tabular}

Through the risk analysis process, this work surveyed fifteen final closing professionals. Table 8 indicates a frequency checklist of respondents per each risk degree, taken above degree together. Final risk degree is determined by the value which shows a great frequency among 'low,' 'moderate,' and 'high.' Thus, as following the risk estimation guideline model for each risk factor through above analysis, impact factors are tide, difference of water surface elevation and flow velocity

TABLE VIII

FINAL RESULT OF RISK DEGREE FOR ENGINEERING RISK

\begin{tabular}{|c|c|c|c|c|c|c|}
\hline \multirow{2}{*}{$\begin{array}{c}\text { Risk } \\
\text { Factor }\end{array}$} & \multirow{2}{*}{$\begin{array}{c}\text { Environmental } \\
\text { Conditions }\end{array}$} & \multirow{2}{*}{ Min. Max. } & \multicolumn{3}{|c|}{ Risk Degree } & \multirow{2}{*}{$\begin{array}{l}\text { Final } \\
\text { Result }\end{array}$} \\
\hline & & & Low & Moderate & High & \\
\hline \multirow{22}{*}{$\begin{array}{l}\text { Plan } \\
\text { Ignores } \\
\text { Weather } \\
\text { Forecast }\end{array}$} & \multirow{3}{*}{$\begin{array}{l}\text { Tide } \\
(\mathrm{m})\end{array}$} & $-2 \sim 2$ & 13 & 1 & 1 & Low \\
\hline & & $2 \sim 6$ & 11 & 3 & 1 & Low \\
\hline & & $6 \sim 9$ & 1 & 5 & 9 & High \\
\hline & \multirow{3}{*}{$\begin{array}{l}\text { Difference of } \\
\text { Water Surface } \\
\text { Elevation } \\
(\mathrm{m})\end{array}$} & $0 \sim 4$ & 10 & 4 & 1 & Low \\
\hline & & $4 \sim 8$ & 7 & 6 & 2 & Low \\
\hline & & $8 \sim 10$ & 0 & 5 & 10 & High \\
\hline & \multirow{4}{*}{$\begin{array}{c}\text { Flow } \\
\text { Velocity }(\mathrm{m} / \mathrm{sec})\end{array}$} & $0 \sim 2$ & 13 & 1 & 1 & Low \\
\hline & & $2 \sim 4$ & 9 & 4 & 2 & Low \\
\hline & & $4 \sim 6$ & 0 & 7 & 8 & High \\
\hline & & $6 \sim 8$ & 0 & 1 & 14 & High \\
\hline & \multirow{4}{*}{$\begin{array}{l}\text { Rainfall } \\
(\mathrm{mm})\end{array}$} & $0 \sim 10$ & 13 & 2 & 0 & Low \\
\hline & & $10 \sim 20$ & 10 & 4 & 1 & Low \\
\hline & & $20 \sim 30$ & 10 & 3 & 2 & Low \\
\hline & & $30 \sim 40$ & 7 & 4 & 4 & Low \\
\hline & \multirow{4}{*}{$\begin{array}{l}\text { Wind } \\
(\mathrm{m} / \mathrm{sec})\end{array}$} & $0 \sim 2.5$ & 13 & 2 & 0 & Low \\
\hline & & $2.5 \sim 5.0$ & 9 & 6 & 0 & Low \\
\hline & & $5.0 \sim 7.5$ & 8 & 4 & 3 & Low \\
\hline & & $7.5 \sim 10$ & 8 & 2 & 5 & Low \\
\hline & \multirow{4}{*}{$\begin{array}{c}\text { Temperature } \\
\left({ }^{\circ} \mathrm{C}\right)\end{array}$} & $-10 \sim 0$ & 10 & 3 & 2 & Low \\
\hline & & $0 \sim 10$ & 8 & 7 & 0 & Low \\
\hline & & $10 \sim 20$ & 9 & 6 & 0 & Low \\
\hline & & $20 \sim 30$ & 10 & 5 & 0 & Low \\
\hline
\end{tabular}

And this research analyzed a tendency of respondent for engineering risk. For example, ' $\mathrm{L}$ ' presents low and ' $\mathrm{M}$ ' presents moderate, and ' $\mathrm{H}$ ' presents high for risk degree. The tendency is divided according to expert's experience. The case study shows that the tendency of experts who have more experience is similar to final risk assessment.

Table 9 shows final risk degree and a risk estimation guideline model. Having the guideline, workers could consult with risk degree for each risk factor in project process. 
FINAL RESUlT OF RISK DEGREE FOR GENERAL RISK

\begin{tabular}{|c|c|c|c|c|}
\hline \multirow{2}{*}{ Risk Factor } & \multicolumn{3}{|c|}{ Risk Degree } & \multirow{2}{*}{$\begin{array}{l}\text { Final } \\
\text { Result }\end{array}$} \\
\hline & Low & Moderate & High & \\
\hline $\begin{array}{l}\text { Error in Plan of Final Closing } \\
\text { Section }\end{array}$ & 0 & 6 & 9 & High \\
\hline $\begin{array}{l}\text { No Consideration for Ground } \\
\text { Condition }\end{array}$ & 1 & 6 & 8 & High \\
\hline $\begin{array}{l}\text { Fault of Expectation Putting } \\
\text { Quantity }\end{array}$ & 1 & 10 & 4 & Moderate \\
\hline $\begin{array}{l}\text { Fault of Management of } \\
\text { Selecting Optimal Construction } \\
\text { Method }\end{array}$ & 3 & 10 & 2 & Moderate \\
\hline $\begin{array}{l}\text { Fault of Treating Additional } \\
\text { Personnel Pay }\end{array}$ & 1 & 11 & 3 & Moderate \\
\hline $\begin{array}{l}\text { Fault of Treating Additional } \\
\text { Equipment Expenses }\end{array}$ & 2 & 9 & 4 & Moderate \\
\hline $\begin{array}{l}\text { Plan of Securing Source } \\
\text { of Supply }\end{array}$ & 3 & 6 & 6 & High \\
\hline $\begin{array}{l}\text { Fault of Taking Measure to Civil } \\
\text { Complaint }\end{array}$ & 2 & 11 & 2 & Moderate \\
\hline
\end{tabular}

And this research analyzed a tendency of respondent for general risk. In Table 10 and 11, 'L' presents low and 'M' presents moderate, and ' $\mathrm{H}$ ' presents high for risk degree. The tendency is divided into two groups according to expert's experience. As you see Table 10, the tendency of experts who have more experience is similar to final risk assessment. But in Table 11, the tendency is not similar to final result, which means that the tendency of risk degree can be varied by expert's experience.

TABLE $X$

ANALYZE TENDENCY FOR GENERAL RISK (OVER TEN YEARS' EXPERIENCE)

\begin{tabular}{l|c|c|c|c|c|c|c|c|c}
\multicolumn{7}{c}{ Risk Factor } & \multicolumn{7}{c|}{ Risk Degree } & \multicolumn{2}{c}{$\begin{array}{c}\text { Final } \\
\text { Result }\end{array}$} \\
\hline Error in Plan of Final Closing Section & H & H & H & H & M & H & H & H & High \\
\hline $\begin{array}{l}\text { No Consideration for Ground } \\
\text { Condition }\end{array}$ & H & H & H & H & M & H & H & H & High \\
\hline Fault of Expectation Putting Quantity & H & M & M & M & M & H & M & M & Moderate \\
\hline Plan of Securing Source of Supply & H & H & H & M & H & M & M & M & High \\
\hline $\begin{array}{l}\text { Fault of Management of Selecting } \\
\text { Optimal Construction Method }\end{array}$ & M & M & M & M & M & M & L & M & Moderate \\
\hline $\begin{array}{l}\text { Fault of Treating Additional Personnel } \\
\text { Expenses }\end{array}$ & M & H & M & M & H & M & M & M & Moderate \\
\hline $\begin{array}{l}\text { Fault of Treating Additional Equipment } \\
\text { Expenses }\end{array}$ & M & M & M & M & H & M & H & M & Moderate \\
\hline $\begin{array}{l}\text { Fault of Taking Measure to Civil } \\
\text { Complaint }\end{array}$ & M & M & L & M & M & M & H & M & Moderate \\
\hline
\end{tabular}

TABLE XI

ANALYZE TENDENCY FOR GENERAL RISK (LESS THAN TEN YEARS' EXPERIENCE)

\begin{tabular}{l|c|c|c|c|c|c|c|c}
\multicolumn{1}{c}{ (LESS THAN TEN YEARS' EXPERIENCE) } \\
\hline \multicolumn{7}{c|}{ Risk Factor } & \multicolumn{7}{c|}{ Risk Degree } & \multicolumn{2}{c}{$\begin{array}{c}\text { Final } \\
\text { Result }\end{array}$} \\
\hline $\begin{array}{l}\text { Error in Plan of Final Closing } \\
\text { Section }\end{array}$ & H & M & M & M & M & M & H & High \\
\hline $\begin{array}{l}\text { No Consideration for Ground } \\
\text { Condition }\end{array}$ & H & M & M & M & M & M & L & High \\
\hline Fault of Expectation Putting Quantity & H & M & M & L & M & H & M & Moderate \\
\hline Plan of Securing Source of Supply & M & H & L & M & L & H & L & High \\
\hline $\begin{array}{l}\text { Fault of Management of Selecting } \\
\text { Optimal Construction Method }\end{array}$ & H & M & M & M & L & H & L & Moderate \\
\hline $\begin{array}{l}\text { Fault of Treating Additional } \\
\text { Personnel Expenses }\end{array}$ & M & M & M & M & M & H & L & Moderate \\
\hline $\begin{array}{l}\text { Fault of Treating Additional } \\
\text { Equipment Expenses }\end{array}$ & H & M & M & L & M & H & L & Moderate \\
\hline $\begin{array}{l}\text { Fault of Taking Measure to Civil } \\
\text { Complaint }\end{array}$ & M & M & M & M & L & H & M & Moderate \\
\hline
\end{tabular}

\section{Risk Response}

This work established risk response list from interviewing with expert and survey. Response list is also divided into two parts; engineering risk and general risk. Actually, in the risk management methodology, risk response is defined by four categories such as risk acceptance, risk avoidance, risk mitigation, risk transfer (Kim, 2010). But in this research, risk response is decided by environment factor and risk assessment because decision standard is ambiguous.

First, it found appropriate response of engineering risk according to environment factor which mostly influences on risk factor. For example, 'Management Plan's Faults at Bad Weather' is largely influenced by tide, difference of water surface elevation, and flow velocity. So, response list is established according to the environment factor by final closing experts. Table 12 is presented as a sample.

And, it found response of general risk according to risk assessment. Decision of responding to general risk is that low risk is ignored, and it concerned about moderate and high risk. For example, risk degree of 'Planning Error of Final Closing Section' is high, so response is established according to risk degree. Table 13 shows the general risk response list as like as table 12 .

TABLE XII

\begin{tabular}{|c|c|c|}
\hline \multicolumn{3}{|c|}{ RESPONSES FOR ENGINEERING RISK (IN BRIEF) } \\
\hline Risk Factor & $\begin{array}{c}\text { Environmental } \\
\text { Conditions }\end{array}$ & Risk Response \\
\hline $\begin{array}{l}\text { Plan Ignores } \\
\text { Weather } \\
\text { Forecast }\end{array}$ & $\begin{array}{c}\text { Tide, } \\
\text { Difference of } \\
\text { Water Surface } \\
\text { Elevation, } \\
\text { Flow Velocity }\end{array}$ & $\begin{array}{l}\text { - Performing work after bad weather } \\
\text { - Performing minimum work at bad } \\
\text { weather } \\
\text { - Accurately analyze weather } \\
\text { forecast for bad weather } \\
\text { - Supplement work plan for bad } \\
\text { weather }\end{array}$ \\
\hline $\begin{array}{l}\text { Fault of } \\
\text { Managing } \\
\text { Quantity of } \\
\text { Soil heap }\end{array}$ & $\begin{array}{c}\text { Flow Velocity, } \\
\text { Rainfall }\end{array}$ & $\begin{array}{l}\text { - Construct without Quantity of Soil } \\
\text { heap } \\
\text { - Putting an equipment additionally } \\
\text { - Construct a shortage of supply in } \\
\text { the future. } \\
\text { - Devise a method for defect } \\
\text { occurrence }\end{array}$ \\
\hline
\end{tabular}

TABLE XIII

RESPONSES FOR GENERAL RISK (IN BRIEF)

\begin{tabular}{c|c|l}
\hline Risk Factor & Risk Degree & \multicolumn{1}{c}{ Risk Response } \\
\hline $\begin{array}{c}\text { Planning Error } \\
\text { Closing } \\
\text { Section }\end{array}$ & High & $\begin{array}{l}\bullet \text { Change method through design change } \\
\text { Plan by an experienced hand } \\
\text { - Define plan guidebook at design }\end{array}$ \\
\hline $\begin{array}{c}\text { No } \\
\text { Consideration } \\
\text { for Ground } \\
\text { Condition }\end{array}$ & Moderate & $\begin{array}{l}\bullet \text { Replace method which doesn't } \\
\text { influence ground }\end{array}$ \\
$\begin{array}{l}\text { Postpone schedule after reinforcing } \\
\text { ground } \\
\text { Accurately examine at design } \\
\text { Reinforce dangerous part in advance }\end{array}$ \\
\hline
\end{tabular}

\section{E. Model validation}

This research performed testing an established risk model in order to prove application of model to actual construction. So, it found historical accident data related to final closing. The historical data is gotten from Rural Development Corporation (1995). They included accident data related to final closing, tidal gate, and riprap 
protection damage in a sea dike construction. The accident data included information which is date, construction situation, environment factor, damage situation, accident's cause and imperfection. The imperfection is inadequacies at building or preparing a final closing construction. Table 14 shows cause and imperfection of accident. The accident region's name is treated anonymity.

TABLE XIY

CAUSES AND IMPERFECTION OF ACCIDENT

\begin{tabular}{|c|c|c|}
\hline $\begin{array}{l}\text { Accident } \\
\text { Name }\end{array}$ & Cause & Imperfection \\
\hline Region D & $\begin{array}{l}\text { Formed flow net because } \\
\text { of repetition of velocity } \\
\text { and concentration of flow } \\
\text { force caused by expansion } \\
\text { of erosion }\end{array}$ & $\begin{array}{l}\text { - Don't construct mattress to } \\
\text { foundation ground of } \\
\text { rubble mound }\end{array}$ \\
\hline Region N & $\begin{array}{l}\text { - Occurrence of whirlpool } \\
\text { because of concentration } \\
\text { of flow at tide } \\
\text { - Expansion of flow net } \\
\text { caused by concentrating } \\
\text { flux }\end{array}$ & $\begin{array}{l}\text { - Establishment of an } \\
\text { impractical official plan } \\
\text { - Fault of construction } \\
\text { related to condition of tide } \\
\text { and ebb } \\
\text { - Fault of application of } \\
\text { mattress and filter theory }\end{array}$ \\
\hline $\begin{array}{l}\text { Region } \\
\text { S-1 }\end{array}$ & $\begin{array}{l}\text { - Lack of putting ability } \\
\text { within schedule of final } \\
\text { closing } \\
\text { - Fault of plan of floor } \\
\text { compaction by comparison } \\
\text { with tide and velocity }\end{array}$ & $\begin{array}{l}\text { - Establishment of an } \\
\text { impractical official plan } \\
\text { - Fault of handling poor } \\
\text { ground foundation } \\
\text { - Fault of decision for } \\
\text { construction ability }\end{array}$ \\
\hline $\begin{array}{l}\text { Region } \\
\text { S-2 }\end{array}$ & $\begin{array}{l}\text { - Formed serious undulation } \\
\text { to surface } \\
\text { - Expansion of flow net } \\
\text { caused by concentrating } \\
\text { flow partially }\end{array}$ & $\begin{array}{l}\text { - Unreasonable decision of } \\
\text { elevation of final closing } \\
\text { floor compaction } \\
\text { - A shortage of weight of } \\
\text { rubble mound to resist flow } \\
\text { velocity }\end{array}$ \\
\hline
\end{tabular}

So, this work found relation between accident data and established risk model in order to match risk model with historical data. Table 15 shows result of model validation with historical data.

TABLE XV

RESULT OF MODEL VALIDATION

\begin{tabular}{|c|c|c|}
\hline $\begin{array}{l}\text { Accident } \\
\text { Name }\end{array}$ & Cause or Imperfection & Risk Factor \\
\hline \multirow{6}{*}{$\begin{array}{l}\text { Region } \\
\mathrm{N}\end{array}$} & $\begin{array}{c}\text { Occurrence of } \\
\text { whirlpool because of } \\
\text { concentration of flow } \\
\text { at tide }\end{array}$ & \multirow{2}{*}{$\begin{array}{l}\text { Mis-calculated of Water } \\
\text { Pressure }\end{array}$} \\
\hline & $\begin{array}{c}\text { Expansion of flow net } \\
\text { caused by } \\
\text { concentrating flux }\end{array}$ & \\
\hline & $\begin{array}{c}\text { Fault of application of } \\
\text { mattress and filter } \\
\text { theory }\end{array}$ & Fault of Building Filter Mat \\
\hline & \multirow{3}{*}{$\begin{array}{l}\text { Establishment of an } \\
\text { impractical official } \\
\text { plan }\end{array}$} & $\begin{array}{c}\text { Time Management } \\
\text { (No Consideration of Work } \\
\text { Delay for each Operation) }\end{array}$ \\
\hline & & $\begin{array}{l}\text { Planning Error of Final } \\
\text { Closing Section }\end{array}$ \\
\hline & & $\begin{array}{l}\text { Fault of Managing } \\
\text { Pre-Scenario }\end{array}$ \\
\hline Region & Lack of putting ability & Fault of Expectation \\
\hline
\end{tabular}

\begin{tabular}{c|c|c}
\hline S & $\begin{array}{c}\text { within schedule of } \\
\text { final closing }\end{array}$ & Putting Quantity \\
\cline { 2 - 3 } & $\begin{array}{c}\text { Establishment of an } \\
\text { impractical official } \\
\text { plan }\end{array}$ & $\begin{array}{c}\text { Fault of Managing Pre- } \\
\text { Scenario }\end{array}$ \\
\cline { 2 - 3 } & $\begin{array}{c}\text { Fault of handling poor } \\
\text { ground foundation }\end{array}$ & $\begin{array}{c}\text { No Consideration for Ground } \\
\text { Condition }\end{array}$ \\
\cline { 2 - 3 } & $\begin{array}{c}\text { Fault of decision for } \\
\text { construction ability }\end{array}$ & $\begin{array}{c}\text { Fault of Control Management } \\
\text { of Construction Manager }\end{array}$ \\
\hline
\end{tabular}

This work matched that cause and imperfection of accident is related to risk factor. As a result of matching data, some item is related to each other. So, when accident happens at that time, if they have risk estimation model which is suggested in this research, they can decrease or avoid accident.

\section{CONCLUSION}

The purpose of this research was to establish a risk estimation model and appropriate response for each risk. And it was to suggest risk guideline model and process in order to decrease and avoid accident or damage during construction.

The data collection focused effort targeted is expert in the field who were asked fill out short questionnaire. Furthermore historical data was collected in order to validate the risk model an actual two cases. The established risk model built on the general risk theory with likelihood and impact.

The following discussed the outcome of this work in relation to the established three hypotheses.

Hypothesis 1: Construction manager will plan decision making by using risk model.

In order to prove the hypothesis, the interviews and survey were performed to experts who have final closing construction experience. It shows that they rarely do risk management during actual construction. Nevertheless, people agreed the necessity of risk management. It shows that most workers are aware of the need of risk management in final closing. Thus, it should be concluded that the experienced workers have consciousness upon the risk in final closing.

Hypothesis 2: Decision process of manager can be captured into a risk model.

In order to prove the hypothesis, risk factors were identified and environmental conditions were drawn based on the interview and survey. Therefore, Table 7 and 8 presents sample of risk degree guideline. They show that the developed risk estimation model in this study reflects decision-making of the experienced workers.

Hypothesis 3: Established risk model will match historical data.

In order to verify, data on past accident related with final closing was analyzed and was compared to risk estimation model. Table 15 presents result of test. It indicates that the identified risk factor by this work matches to the case and the flaw of the accident. Also, the responsive method 
suggested by the study can be applied to them. Thus, the proposed risk estimation model is applicable in practice.

This work gives some recommendations. First, risk factor should be added in various environments because this research is preceded in the western sea. Next, risk model program should be developed by VBA (Visual Basic for Applications). For example, automatically register risk, calculate risk assessment, and find response. Lastly, suggested form such as risk assessment model, risk management process may be applied to any different construction.

\section{REFERENCES}

[1] O. Choi, J.W. Seo, B.J. Choi, H.H. Choi, "Risk-based Safety Impact Assessment Methodology for Construction Projects", journal of the Korean Society of Civil Engineers, vol. 25, no. 6D, pp. 847-855, 2005.

[2] L. Edwards, "Practical Risk Management in the Construction Industry", Thomas Telford, 1995.

[3] S.H. Kang, "A Study for Construction Risk Management Method on Final Closing Section of the Sea Dike", M.S. Dissertation, Hanyang University, 2010.

[4] I.H. Kim, "Risk Management in the Construction Projects", Ki Moon Dang, 2004

[5] K.H. Kim, J.S. Choi, S.H. Shin, C.H. Yang, "Analysis of the Risk Factors in Demolition", journal of Architectural Institute of Korea, vol. 24, no. 1, pp. 151-158, 2008.

[6] S.K. Kim, "Construction Risk Management", Ki Moon Dang, 2010

[7] Korea Development of Farmland Laboratory, "A Study on Plan Damage Control and Optimum Section during Building a Breakwater", KDFL, 1995

[8] Korea Hydrographic Oceanographic Administration, www.khoa.go.kr.

[9] Korea Meteorological Administration, www.kma.go.kr.

[10] Korea Occupational Safety \& Health Agency, www. kosah.or.kr.

[11] Korea Rural Community Corporation, "A Study on Development of Safety Management System for Tidal Gate in Sae Man Keum", KRCC, 2006.

[12] Ministry of Land, Transport and Maritime Affairs, www.mltm.go.kr.

[13] J.S. Park, C.T. Hyun, T.H. Hong, S.H. Park, H.S. Moon, "Development of Checklist for Improving Constructability in Steel Structure Construction", journal of Architectural Institute of Korea, vol. 25, no. 12, pp.197-206, 2009.

[14] Project Management Institute, "A Guide to Project Management Body of Knowledge", The National Information Standards Organization, 2008.

[15] D. Rothkopf, "Managing risk", The Swiss Banker Journal, vol. 4 , no. 8, pp.73-80, 1975 .

[16] Korea Rural Development Corporation, "Tideland Reclamation in Korea”, Korea Rural Development Corporation, 1995.

[17] K.Y. Shin, H.S. Cha, "Risk-Based Performance Evaluation and Prediction Tool by Characterizing Construction Projects in PreProject Planning", Korean Journal of Construction Engineering and Management, vol. 9, no. 5, pp.168-175, 2008. 